\title{
Bioactivity of aqueous and organic extracts of sea cucumber Holothuria leucospilota (Brandt 1835) on pathogenic Candida and Streptococci
}

\author{
Motahereh Ghadiri • Soodabeh Kazemi • Behrooz Heidari • \\ Mehdi Rassa
}

Received: 15 April 2017/ Accepted: 15 December 2017/Published online: 6 January 2018

(C) The Author(s) 2018. This article is an open access publication

\begin{abstract}
Holothurians (sea cucumbers) exist almost in all benthic marine environments and they are an important species for the commercial fisheries. In this study, the antimicrobial activity of different tissues of the sea cucumber, as a marine invertebrate, was investigated. The bacteria, Streptococcus mutans and Streptococcus sobrinus, the fungi, Candida parapsilosis, Candida albicans and Candida glabrata, were chosen for antimicrobial test, because they are opportunistic pathogens. The body wall, respiratory tree, and gastrointestinal tract of the sea cucumbers were utilized to make the extracts. Phosphate-buffered saline (PBS), ethanol (Et), and acetonitrile (ACN) were used as solvents for aqueous and organic extractions. The results showed that there were antimicrobial active compounds against infective streptococci and candid fungi. Streptococcus mutans was generally more tolerant than Streptococcus sobrinus to the sea cucumber extracts. The extracts of the respiratory tree with ACN and PBS, as solvents, showed the highest effect against Candida albicans, Candida parapsilosis and Candida glabrata. The extracts of gastrointestinal tract and the body wall with Et and PBS, respectively, had not any antifungal activity. The antimicrobial activities had been found in different extracts of the sea cucumber tissues, which could be related to the protein and non-protein compounds.
\end{abstract}

Keywords Antimicrobial activity $\cdot$ Candida $\cdot$ Sea cucumber $\cdot$ Streptococcus

\section{Introduction}

During the last decades, the marine natural products have been attracted much attentions of biologists and chemists of all around the world. Marine organisms produce natural products which can be pharmaceutically useful or being a toxic compound. During the last decade, researches on marine crustaceans, sponges, jellyfish, sea anemones, corals, bryozoans, mollusks, tunicates and echinoderms have been increased, and these investigations have been specially focused on desirable antimicrobial properties (Bhakuni and Rawat 2005; Casas et al. 2011; Haug et al. 2002). Echinoderms are a group of benthic organisms, which are exposed to relatively high concentrations of pathogens which can be harmful to the animal (Haug et al. 2002). Sea cucumbers are a class of Holothuroidea with body shape of a worm and without any spines.

M. Ghadiri · S. Kazemi · B. Heidari $(\bowtie) \cdot$ M. Rassa

Department of Biology, Faculty of Science, University of Guilan, Namjoo St., Rasht 4193833697, Iran

e-mail: Bheidari@guilan.ac.ir; Behrooz1072@yahoo.com

B. Heidari

Department of Marine Sciences, Caspian Sea Basin Research Center, University of Guilan, Rasht, Iran 
Many sea cucumbers have novel defensive mechanisms which compensates their lack of spines (Lewbart 2006). The sea cucumbers have multiple biological activities such as wound healing (Fredalina et al. 1999), antibacterial (Gowda et al. 2008; Haug et al. 2002; Kiani et al. 2014; Ridzwan et al. 1995), antifungal (Wang et al. 2012), agglutinating activities (De Melo et al. 2014; Gowda et al. 2008) and antioxidant properties (Osama et al. 2009).

Different habitats of human oral cavity such as teeth, gingival sulcus, tongue, cheeks, hard and soft palates, and tonsils can be colonized easily by bacteria (Dewhirst et al. 2010). The oral diseases including dental caries created by aerobic and anaerobic bacteria are of the most major health problems in the world (Aas et al. 2008; Anusavice 2002; Becker et al. 2002; Beighton 2005; Chhour et al. 2005). The streptococci are the major dental caries aetiologic agents and they are the most common pathogens isolated from the human dental plaque and play an important role in the development and progression of dental caries (Nishikawara et al. 2006; Okada et al. 2005). Streptococcus mutans (Clark 1924) and Streptococcus sobrinus (Coykendall 1974) are the two species which are responsible for the dental caries (Ghasempour et al. 2013; Nascimento et al. 2004; Okada et al. 2005). These groups of bacterial species are characterized by their ability of producing extracellular glucans from sucrose and via their acidic productions in animal and human studies (Ghasempour et al. 2013; Nishikawara et al. 2006).

The Candida strains are the main factor for serious fungal infections such as vulvovaginal candidiasis (VVC) which can infect $75 \%$ of adult women during their life (Sharanappa and Vidyasagar 2013), and it also increases the chance of cutaneous infections, vaginitis, intestinal and systemic infections (Molero et al. 1998). The Candida strains are considered to be the fourth effective factor in hematological infections for patients hospitalized and this kind of infection is responsible for about $40 \%$ of death (Anaissie et al. 2003). The opportunistic fungal strains such as $C$. albicans are more frequent than other species and they can be isolated from oral infections (Kantarcioglu and Yucel 2002). The other Candida species with direct effects can cause systemic infections in immunosuppressant patients (such as AIDS, cancer patients and solid-organ transplant recipients). Because of the pathogenic microbe resistances to the conventional antibiotics, the calls for the investigations on new antimicrobials metabolites have been increased. The marine biological reserves, especially 17 species of Holothurians (Dabbagh et al. 2011) of the Persian Gulf, have high potential for antimicrobial investigations, but their biological benefits are unknown due to their unfamiliarity. Therefore, in this work, the antimicrobial effects of various extracts of different tissues of the Persian Gulf sea cucumber on the infectious oral streptococci and Candida strains were investigated.

\section{Materials and methods}

Sampling and preparation of specimens

Live specimens of the sea cucumbers $(N=10)$ were collected via scuba diving off (4-5 $\mathrm{m}$ depth) from Qeshm Island of the Persian Gulf in October (Fig. 1). The samples were transferred on ice to the Marine Biology Laboratory of the University of Guilan. After dissection, all tissues of animals including body wall, respiratory tree and gastrointestinal tract were separately frozen in liquid nitrogen for 5 min and stored at $-70{ }^{\circ} \mathrm{C}$ until the extraction process. The specimens were identified using ossicles obtained from the epidermal tissues of dorsal and ventral surfaces of the body wall (Kiani et al. 2014).

Preparation of extracts

\section{PBS extract}

The tissues (body wall, respiratory tree and gastrointestinal tract) were separately homogenized (Misonix Sonicator 3000, USA) with PBS $\left(\mathrm{NaH}_{2} \mathrm{PO}_{4} \cdot 2 \mathrm{H}_{2} \mathrm{O}, 0.1 \mathrm{M} ; \mathrm{NaOH}, 0.2 \mathrm{M}\right)(1: 5 \mathrm{w} / \mathrm{v})$ for $5 \mathrm{~min}$. The obtained samples were shaken (Infros, RFI-150) on ice for $2 \mathrm{~h}$ at $120 \mathrm{rpm}$ and then they were centrifuged at $4000 \mathrm{rpm}$ for $10 \mathrm{~min}$ at $4{ }^{\circ} \mathrm{C}$. The supernatants were collected and stored at $4{ }^{\circ} \mathrm{C}$, and the residues were centrifuged in two volumes of PBS. Then, the combined supernatants were centrifuged and lyophilized by freeze-dryer 


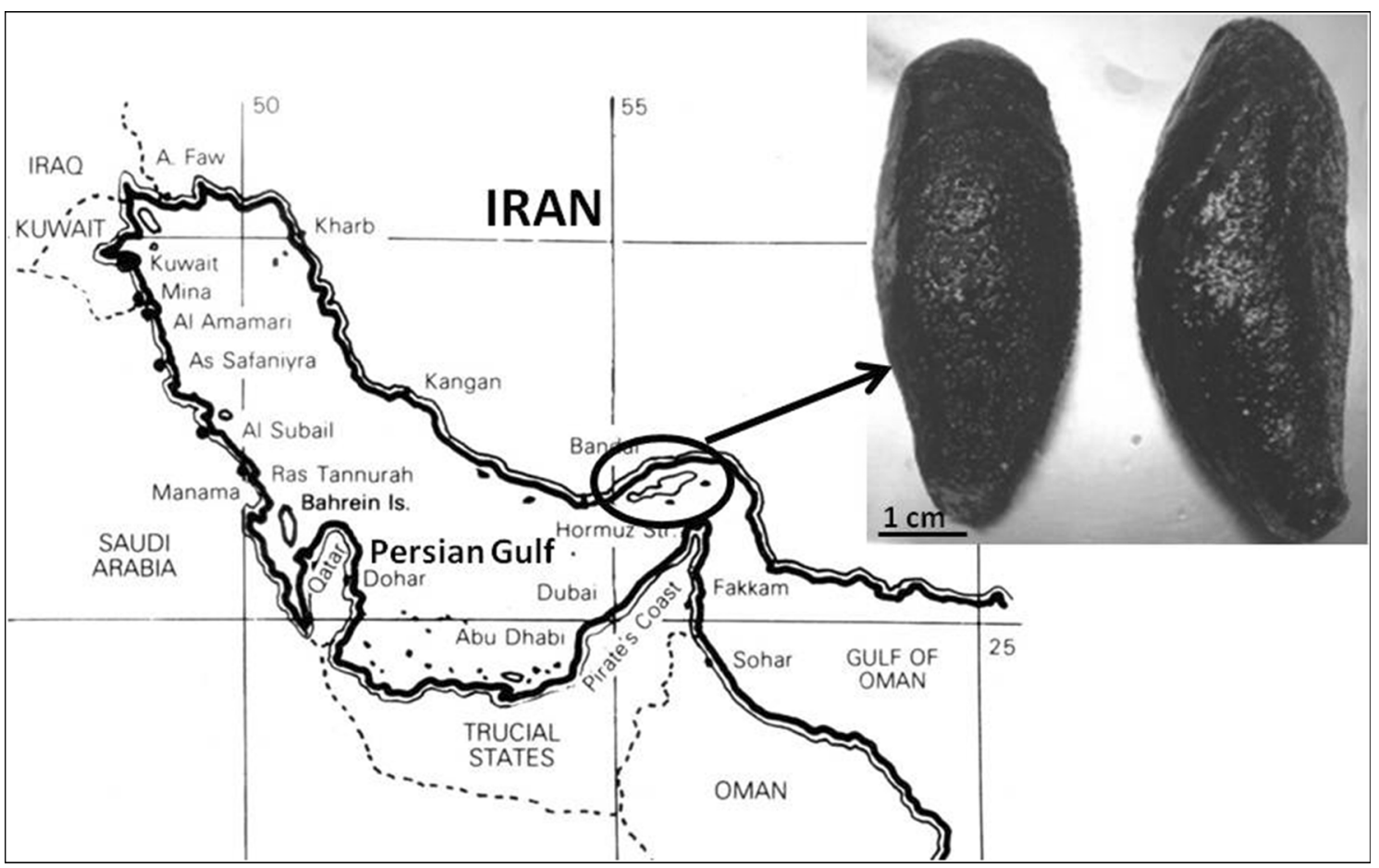

Fig. 1 Map of the Persian Gulf indicating the sampling area and the sea cucumber collected for the study

(Christ Alpha 1-2/LD, Osterode am Harz, Germany) for $9 \mathrm{~h}\left(-55^{\circ} \mathrm{C}\right.$ and $\left.0.02 \mathrm{mbar}\right)$ and they were stored at $-70{ }^{\circ} \mathrm{C}$ until antibacterial test.

\section{Et and ACN extracts}

The organic extracts have been prepared with Et $96 \%$ and ACN (Merck Schuchardt, Germany). As above, all tissues were separately homogenized in Et and ACN with combination of $(1: 5 \mathrm{w} / \mathrm{v})$ for $5 \mathrm{~min}$. Subsequently, the solutions were shaken at $40{ }^{\circ} \mathrm{C}$ for $24 \mathrm{~h}(120 \mathrm{rpm})$ and centrifuged at $4000 \mathrm{rpm}$ for $10 \mathrm{~min}$ at $4{ }^{\circ} \mathrm{C}$. The supernatants were sampled and the residues were centrifuged in two volumes of the solvents. Finally, the collected supernatants were lyophilized by freeze-dryer for $9 \mathrm{~h}\left(-55^{\circ} \mathrm{C}\right.$ and $\left.0.02 \mathrm{mbar}\right)$ and stored at $-70{ }^{\circ} \mathrm{C}$ until antibacterial test.

\section{Bacterial and yeast strains}

The Gram-positive bacteria Streptococcus mutans (ATCC 35668) and Streptococcus sobrinus (ATCC 27607) were purchased from the Persian Type Culture Collection (PTCC, Tehran, Iran) and were used as test microorganisms. The strains were grown on blood agar (Biolife, Italy) containing $7 \%$ fresh horse blood and maintained at $37{ }^{\circ} \mathrm{C}$ for $48 \mathrm{~h}$. The candida strains Candida albicans (5027 ATCC 10231), C. parapsilosis (5297 DSM 11226) were obtained from the Persian Type Culture Collection (PTCC, Tehran, Iran) as well as C. glabrata (30005) was purchased from Iranian Biological Resource Center (IBRC-M, Tehran, Iran).

Antibacterial test

The antibacterial activities of the aqueous (PBS) and organic extractions were evaluated by the well diffusion method (Kiani et al. 2014). S. mutans and S. sobrinus were cultured in blood agar for $24 \mathrm{~h}$. The crude aqueous and organic extracts were tested separately with two concentrations of 600 and $1500 \mu \mathrm{g}$ were dissolved in 40 $\mu \mathrm{L}$ of double distilled water (d.d. $\mathrm{H}_{2} \mathrm{O}$ ) and dimethyl sulfoxide (DMSO) (Merck, Germany) as solvents, respectively. After that, the dissolved extracts were transferred into the wells (diameter $6 \mathrm{~mm}$ ), punched out 
on plates, containing the bacteria and incubated at $37{ }^{\circ} \mathrm{C}$ for $24 \mathrm{~h}$. The antibacterial activities were determined by measuring the diameter of zone of inhibition $(\mathrm{mm})$.

\section{Controls}

Vancomycin $\left(30 \mu \mathrm{g} \mathrm{disc}^{-1}\right)$, Tetracycline $\left(30 \mu \mathrm{g} \mathrm{disc}^{-1}\right)$, Chloramphenicol $\left(30 \mu \mathrm{g} \mathrm{disc}^{-1}\right)$, Nalidixic acid $\left(30 \mu \mathrm{g} \mathrm{disc}{ }^{-1}\right)$, Sulfadiazine $\left(1.0 \mu \mathrm{g} \mathrm{disc}^{-1}\right)$, Oxacillin $\left(1 \mu \mathrm{g} \mathrm{disc}{ }^{-1}\right)$, Bacitracin $\left(15 \mu \mathrm{g} \mathrm{disc}{ }^{-1}\right)$, and Cefepime $\left(30 \mu \mathrm{g} \mathrm{disc}^{-1}\right)$ were utilized as positive controls. DMSO $\left(40 \mu \mathrm{L}\right.$ well $\left.{ }^{-1}\right)$ and $\mathrm{dd}^{\mathrm{H}} \mathrm{H}_{2} \mathrm{O}\left(40 \mu \mathrm{L}\right.$ well $\left.{ }^{-1}\right)$ were also tested as negative controls to ensure that they did not interfere with the tests.

Antifungal test

The antifungal activities of the sea cucumber extracts were evaluated using Sabouraud Dextrose Agar (SDA) well diffusion method (Periyasamy et al. 2012; Stepanovic et al. 2003) against Candida albicans (Persian Type Culture Collection (PTCC): 5027 ATCC 10231), C. parapsilosis (PTCC: 5297 DSM 11226) and C. glabrata (Iranian Biological Resource Center (IBRC-M): 30005). All Candida strains were unloaded from lyophilized ampoules to SDA media after dissolving in $0.5 \mathrm{~mL}$ of the distilled water and cultivated by linear method. The organic and aqueous extracts with two concentrations of 600 and $1500 \mu \mathrm{g}$ were dissolved in 30 $\mu \mathrm{L}$ of DMSO and $30 \mu \mathrm{L}$ of distilled water, respectively. All extractions were added to the labeled wells with diameter $6 \mathrm{~mm}$ on the plates containing the fungi, and then, the loaded plates were incubated at $37{ }^{\circ} \mathrm{C}$ for $24 \mathrm{~h}$.

\section{Controls}

Three antibiotics drugs including Ketoconazole, Fluconazole and Nystatin (with concentration $30 \mu \mathrm{g} \mathrm{mL}^{-1}$ ) were prepared to be used as positive controls, DMSO $\left(40 \mu \mathrm{L}\right.$ well $\left.{ }^{-1}\right)$ and distilled water $\left(40 \mu \mathrm{L}\right.$ well $\left.{ }^{-1}\right)$ were also utilized as negative controls.

Hemolytic assay

To test whether the sea cucumber contain factors that display toxic effect on eukaryotic cells, the hemolytic activity of aqueous and organic extracts obtained from body wall, respiratory tree and gastrointestinal tract was determined. The assay was performed using the method described by Haug et al. (2002). Briefly, heparinized horse red blood cells (RBCs) washed three times in PBS (pH 7) and they were suspended in PBS to reach to a hematocrit value of $10 \%$. The samples were diluted to a protein concentration of $500 \mu \mathrm{g} \mathrm{mL}^{-1}$. The test mixture consisted of $40 \mu \mathrm{L}$ PBS, $50 \mu \mathrm{L}$ extract, and $10 \mu \mathrm{L}$ of the RBCs suspension which was incubated at $37{ }^{\circ} \mathrm{C}$ for $1 \mathrm{~h}$ and then it was centrifuged at $3000 \mathrm{rpm}$ for $10 \mathrm{~min}$. Finally, the absorbance of the supernatants $(60 \mu \mathrm{L})$ was measured at wavelength of $550 \mathrm{~nm}$. Baseline hemolysis and 100\% hemolysis were defined as the amount of hemoglobin released in the presence of PBS and 0.1\% Triton X-100 (Sigma), respectively.

Specimen determination

The specimens were identified using the ossicle of the sea cucumber. After taking digital photographs of ossicle, the identification of species was performed via the diagnostic keys (Price 1981).

Statistical analysis

The raw data were initially tested versus the assumptions of normality and homogeneity of variance. Levene's test and Kolmogorov-Smirnov test were used to assess the homogeneity and normality of variance, respectively. The variances of the populations from which different samples were drawn were equal. The oneway ANOVA followed by Duncan test with a confidence level of $95 \%$ were used to determine the differences between various extracts using IBM SPSS Statistics 19. The significant differences between the two 
concentrations of 600 and $1500 \mu \mathrm{g}$ well ${ }^{-1}$ were assessed by independent $t$ test. All experiments (treatments and controls) were carried out for three times and the obtained data were reported as the mean \pm SD.

\section{Results}

Due to the dorsal and ventral ossicles obtained from epidermal tissues of the body wall, it was concluded that the studied species was Holothuria leucospilota (Brandt 1835) (Fig. 2).

Due to the results, all tissues of the echinoderm species showed antimicrobial activities against oral streptococci and Candida sp.

Extract activities against S. Sobrinus and S. mutans

At concentration of $1500 \mu \mathrm{g}$ well ${ }^{-1}$ of the various extracts of different tissues, antibacterial effects against $S$. sobrinus and S. mutans were observed (Fig. 3). The maximum diameter of inhibition zones (statistically significant, at $p<0.05$ level) was belonged to the ACN extract of the respiratory tree and Et extract of the body wall, while the other extracts showed similar inhibitory effects on the growth of S. sobrinus (statistically insignificant, at $p>0.05$ level) (Fig. 3).

At concentration of $1500 \mu \mathrm{g}$.well ${ }^{-1}$, the maximum diameter of inhibition zone against $S$. mutans was obtained by the PBS extract of gastrointestinal tract $(9.67 \mathrm{~mm})$ while the ACN extracts of gastrointestinal tract
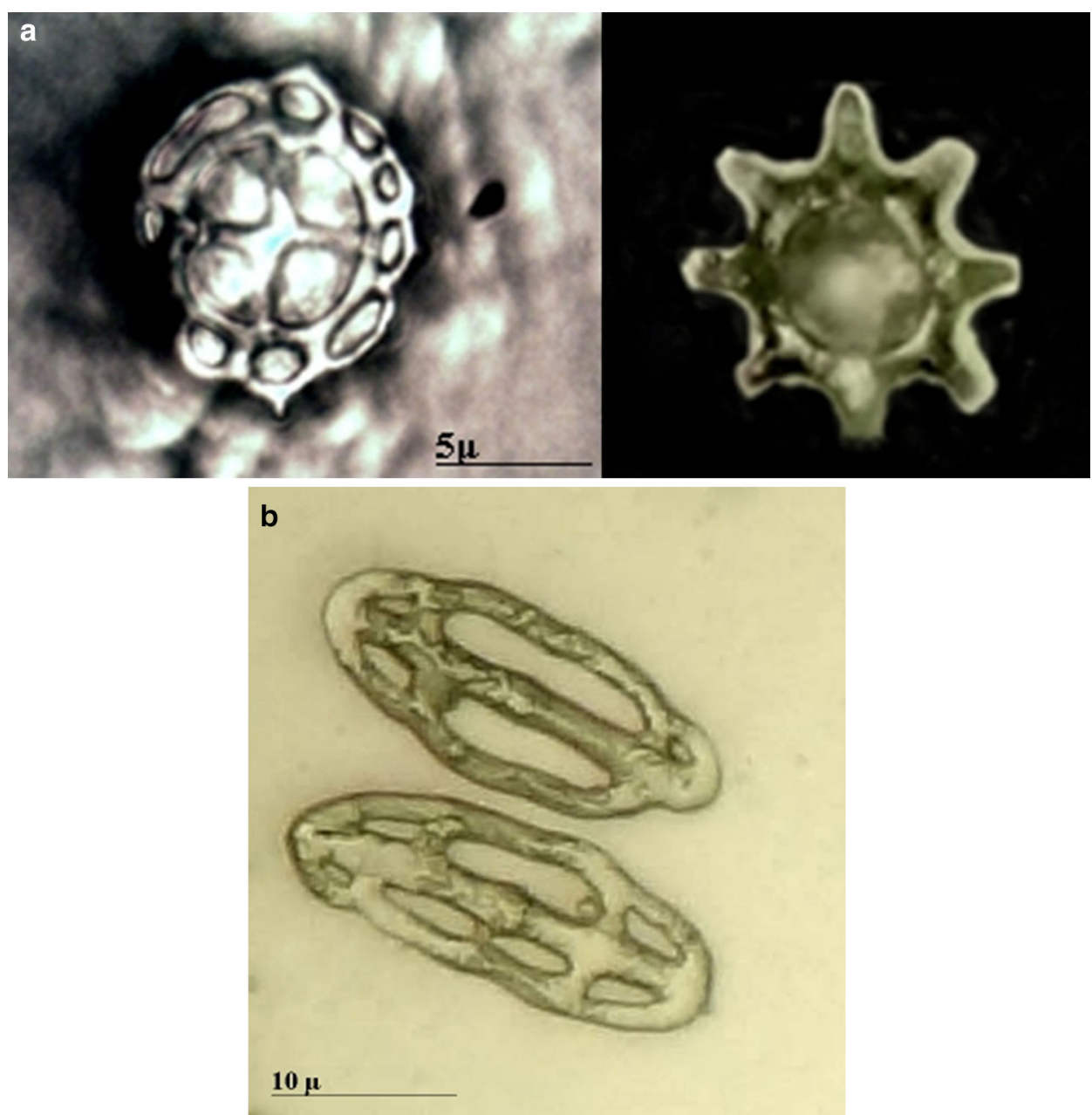

Fig. 2 The dorsal (a) and ventral (b) ossicles of sea cucumber that were used to determine the species 


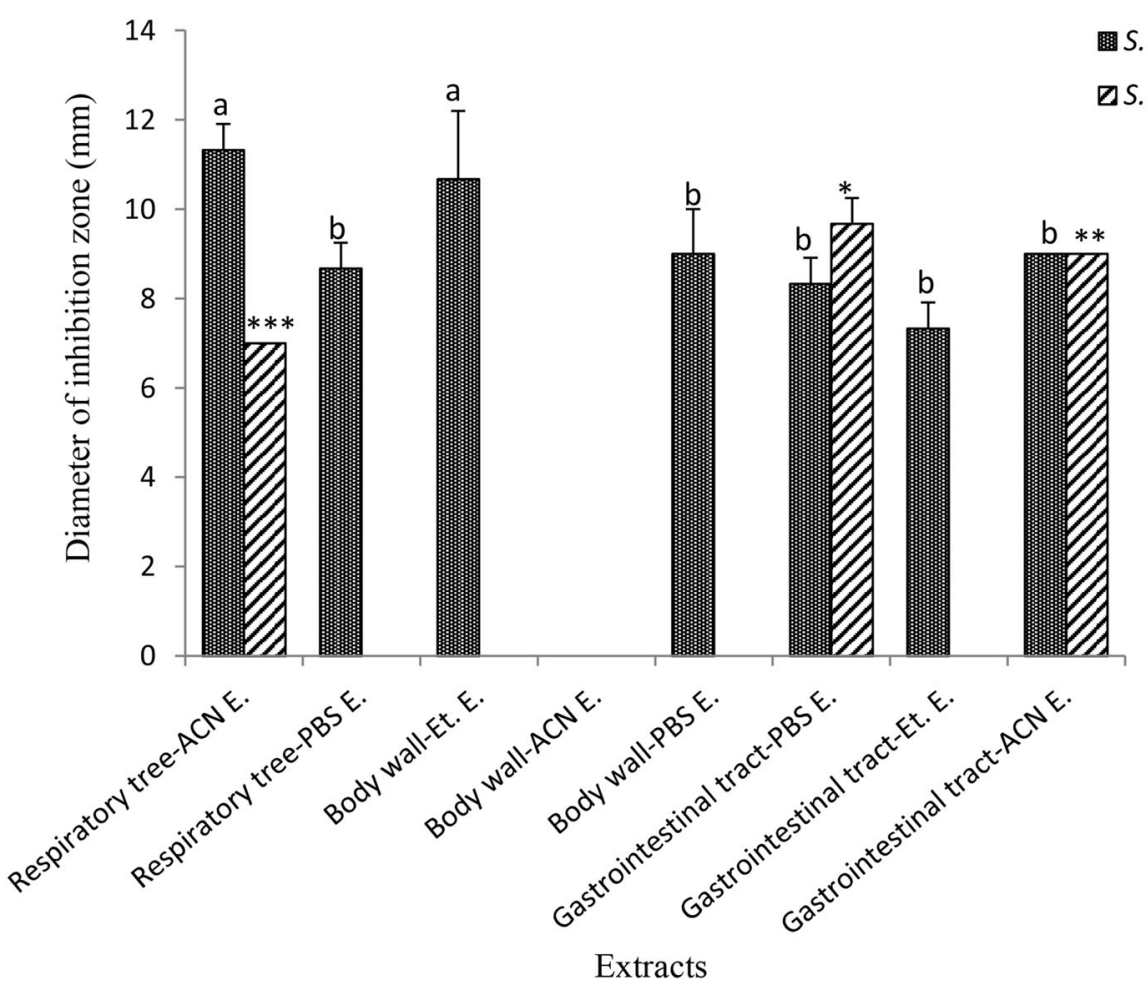

Fig. 3 The mean diameter of inhibition zone for S. sobrinus and S. mutans under the effect of different extracts of $H$. leucospilota with concentrations of $1500 \mu \mathrm{g}$ well ${ }^{-1}$. Mean values bearing different superscripts are significantly different $(p<0.05)$

and respiratory tree had less significant inhibitory effects, respectively $(p<0.05)$ (Fig. 3). The other extracts had no effects on $S$. mutans.

The ACN and Et extracts of gastrointestinal tract, at concentration of $600 \mu \mathrm{g}$ well ${ }^{-1}$, had no antibacterial effects against $S$. sobrinus. The highest antibacterial effect on $S$. sobrinus was observed for the ACN extract of the respiratory tree $(p<0.05)$ (Fig. 4). There was no significant difference $(p>0.05)$ between the antibacterial effects of the various extracts of the body and the PBS extract of gastrointestinal tract (Fig. 4). The Et extract of the respiratory tree had no effect on $S$. sobrinus at both concentrations.

In concentration of $600 \mu \mathrm{g}$ well ${ }^{-1}$, only the PBS extract of gastrointestinal tract had inhibitory effect on the growth of S. mutans (Fig. 4).

The comparison of antibacterial effects of two concentrations using statistical independent $t$ test showed that the extracts with concentration of $1500 \mu \mathrm{g}$ well ${ }^{-1}$ had overall more significant effect $(p<0.05)$ against $S$. sobrinus and S. mutans (Fig. 5a, b).

Activity of extracts with a concentration of $600 \mu \mathrm{g} \cdot \mathrm{well}^{-1}$ against Candida $s p$.

The ACN extract of the respiratory tree and the body wall had significantly the maximum and minimum inhibitory effects on the growth of $C$. parapsilosis, respectively $(p<0.05)$ (Fig. 6). The other extracts had no significant antifungal activity $(p>0.05)$.

The ACN extracts of the body wall, respiratory tree and gastrointestinal tract showed the highest antifungal activity on C. albicans and followed by the Et extracts of the respiratory tree and body wall $(p<0.05)$ (Fig. 6).

The maximum inhibitory activity against $C$. glabrata belonged to the PBS extract of the respiratory tree and followed by the ACN extract of the body wall $(p<0.05)$. In addition, there were no significant differences between antifungal effects of the ACN extract of the respiratory tree and the PBS extract of gastrointestinal tract $(p>0.05)$ (Fig. 6). 


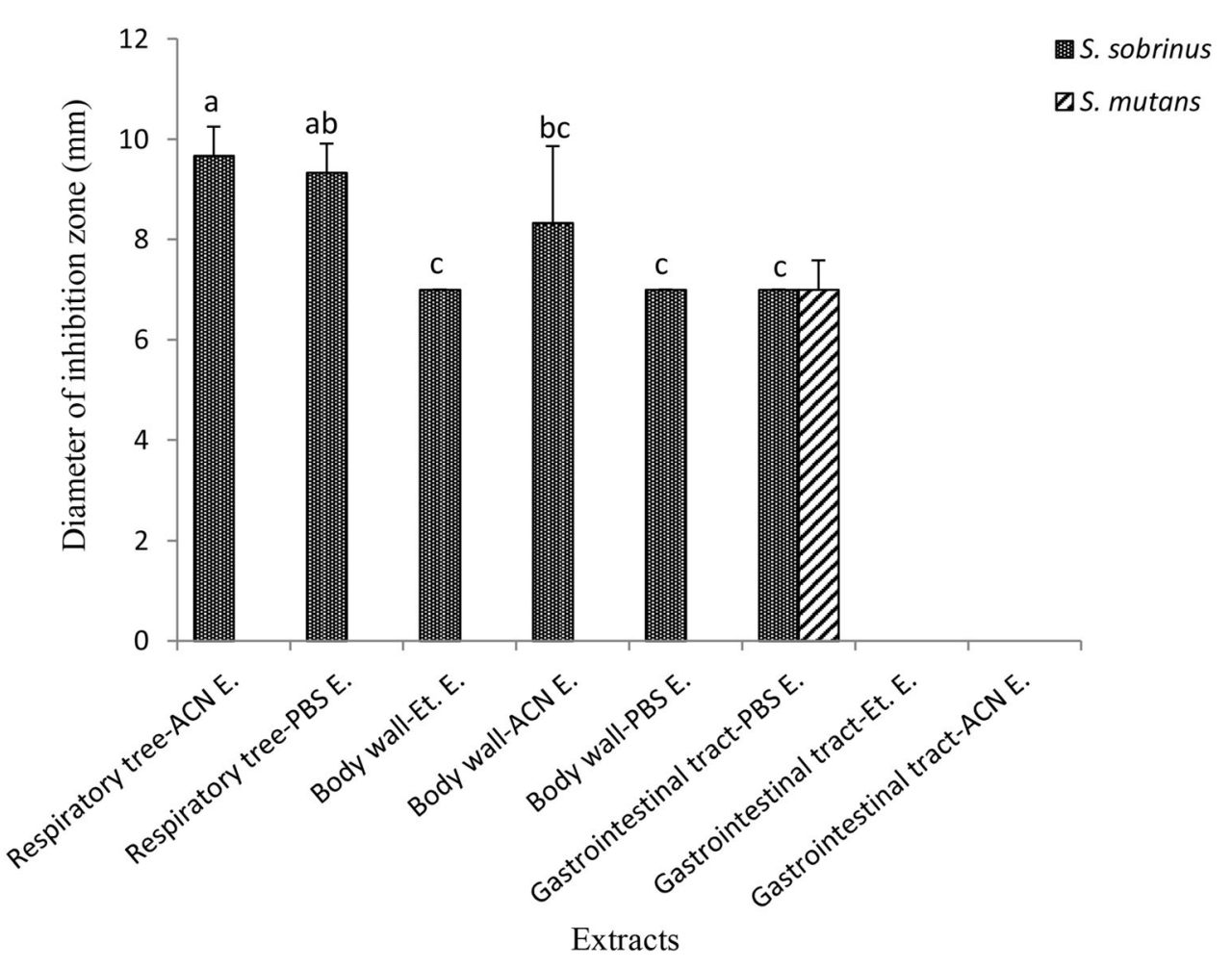

Fig. 4 The mean diameter of inhibition zone for S. sobrinus and S. mutans under the effect of different extracts of H. leucospilota with concentrations of $600 \mu \mathrm{g}$ well ${ }^{-1}$. Mean values bearing different superscripts are significantly different $(p<0.05)$

Activity of extracts with a concentration of $1500 \mu \mathrm{g} \cdot \mathrm{well}^{-1}$ against Candida $s p$.

The Et. extracts of all tissues of the sea cucumber had significantly higher antifungal activities than the other extracts against $C$. parapsilosis $(p<0.05$ ) (Fig. 6). The ACN extracts of all tissues had the same antifungal effects $(p>0.05)$.

The maximum inhibitory activity against $C$. albicans remarkably belonged to the ACN extract of the respiratory tree $(p<0.05)$ (Fig. 7). The ACN and Et extracts of the gastrointestinal tract as well as the Et extract of the body wall had the same inhibitory effects $(p>0.05)$.

The extracts of the different tissues of the sea cucumber showed the diverse significant antifungal effects on C. glabrata (Fig. 7). The ACN extract of the respiratory tree had significantly the maximum inhibitory effect $(p<0.05)$. The Et and PBS extracts like ACN extracts of the respiratory tree and gastrointestinal tract had the minimum antifungal effects $(p<0.05)$. In addition, the ACN extract of the body wall and PBS extract of the gastrointestinal tract had higher effect than Et extract of the body wall $(p<0.05)$ (Fig. 7).

Hemolytic activity of the sea cucumber extracts

The hemolytic activity of the PBS, Et and ACN extracts from the body wall, respiratory tree and gastrointestinal tract of $H$. leucospilota was evaluated using horse red blood cells. Several extracts showed high hemolytic activity (Table 1). In general, the highest and lowest hemolytic activities were obtained from the ACN and PBS extracts of all tissues, respectively. In addition, the antimicrobial activity of the positive and negative controls against the bacteria and fungi was summarized in Figs. 8 and 9. 

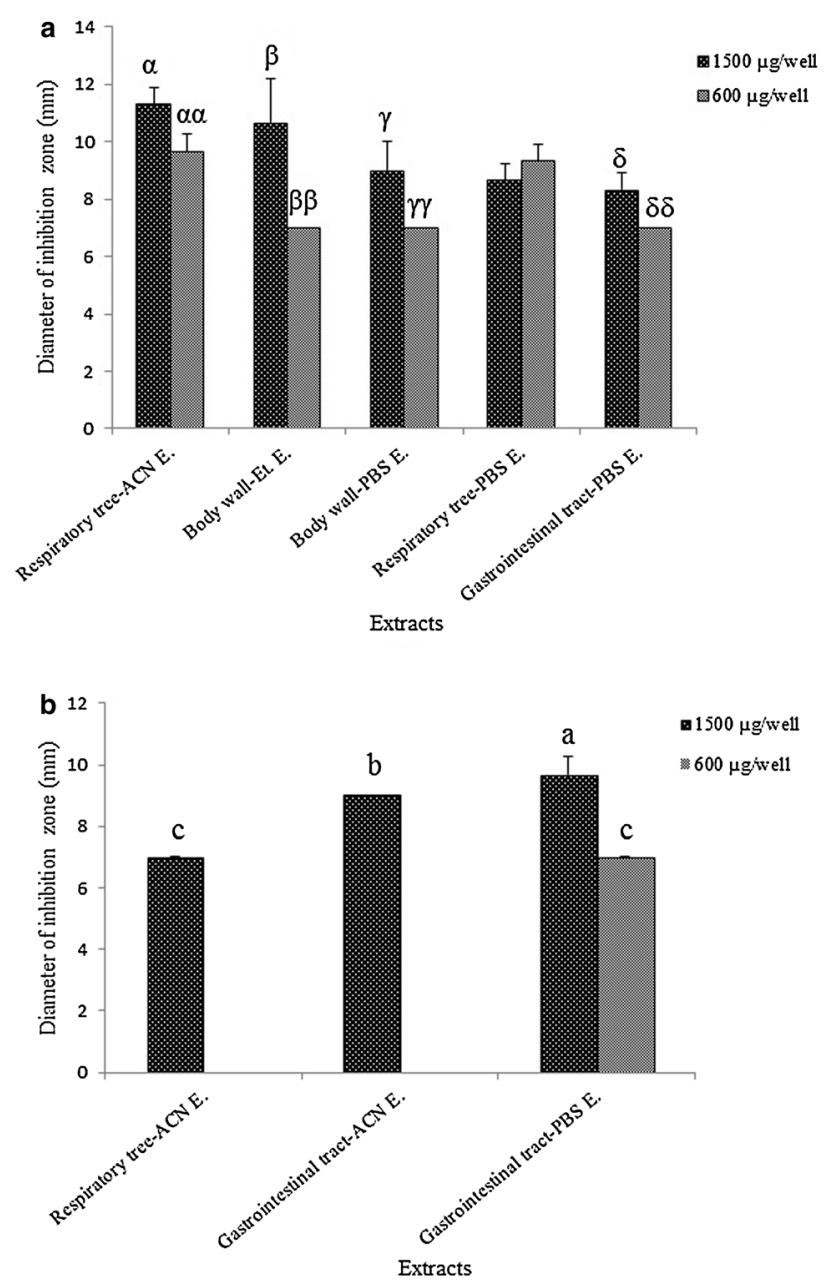

Fig. 5 The comparison between two concentrations of the extracts against S. sobrinus (a), S. mutans (b). Mean values bearing different superscripts are significantly different $(p<0.05)$

\section{Discussion}

Marine organisms have high positions in traditional medical sciences and they also utilize as the main sources for pharmacological investigations (Fenical 1996). It has been discovered that echinoderms have stronger antibacterial effects than Porifera, Mollusca, Bryozoa or Annelida (Ridzwan et al. 1995). The sea cucumbers are benthic animals with no shell and they do not have the ability to escape from predators but they have some effective chemical responses. In this study, it had been tried to evaluate the antimicrobial effects of the various extracts of the different parts of the sea cucumber Holothuria leucospilota on oral streptococci and Candida strains. These extracts with different solvents (Et, ACN and PBS) allowed us to investigate the presence of antimicrobial activity of the substances potentially presented in the lipid- or water-soluble fraction. Since the antimicrobial effects in the different tissues of $H$. leucospilota with various solvents were found, therefore it was concluded that the protein and non-protein factors could be responsible for such effects.

Antibacterial effects of the extracts

The antibacterial activity has previously been described in some species of echinoderms (Gowda et al. 2008; Haug et al. 2002; Kazemi et al. 2016; Kiani et al. 2014; Ridzwan et al. 1995). Haug et al. (2002) studied the antibacterial activity of different parts of the green sea urchin Strongylocentrotus droebachiensis (Müller, 1776), the common starfish Asterias rubens (Linnaeus, 1758) and the sea cucumber Cucumaria frondosa 


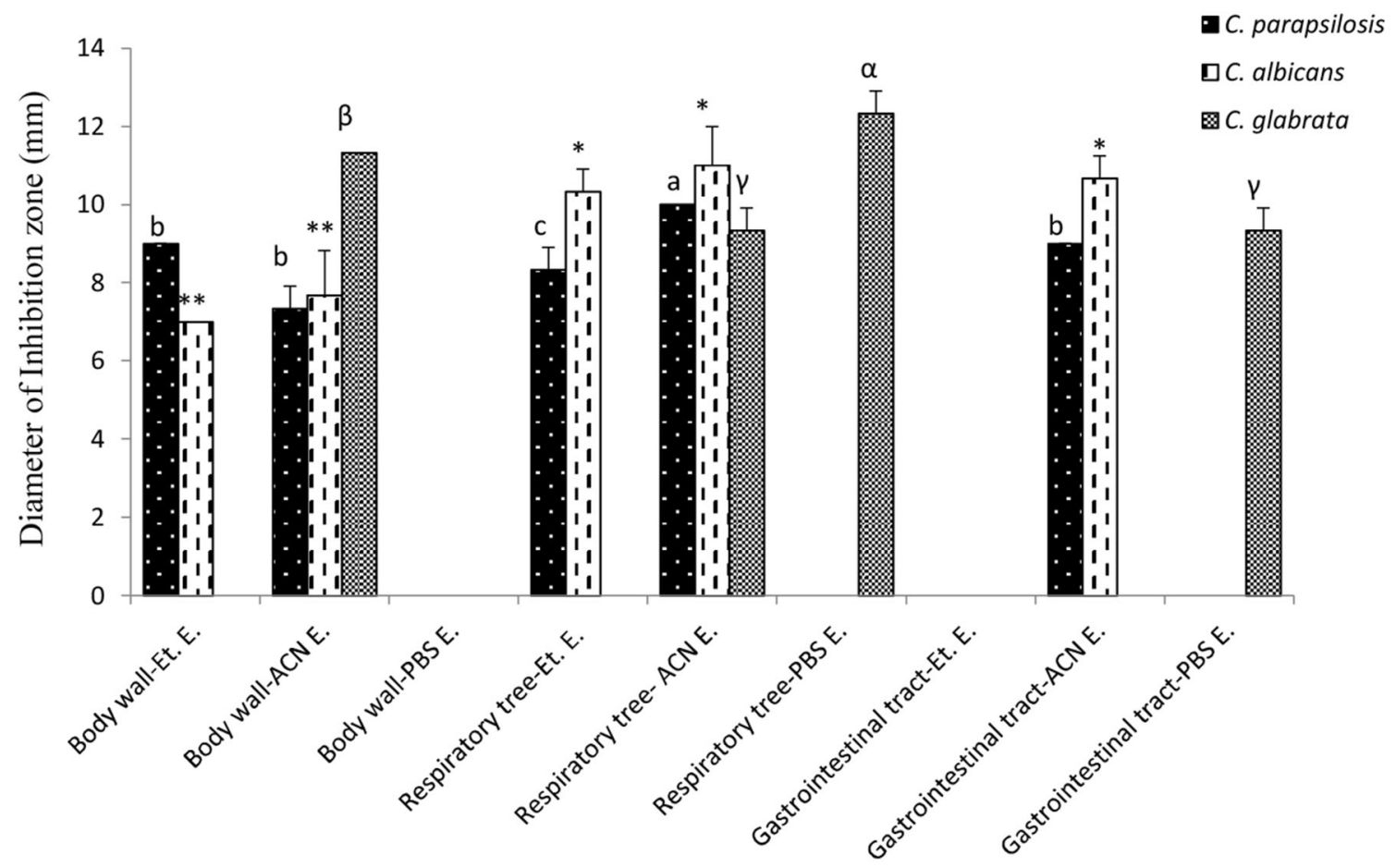

Extracts

Fig. 6 The mean diameter of inhibition zone for Candida sp. under the effect of different extracts of H. leucospilota with concentrations of $600 \mu \mathrm{g}$ well ${ }^{-1}$. Mean values bearing different superscripts are significantly different $(p<0.05)$

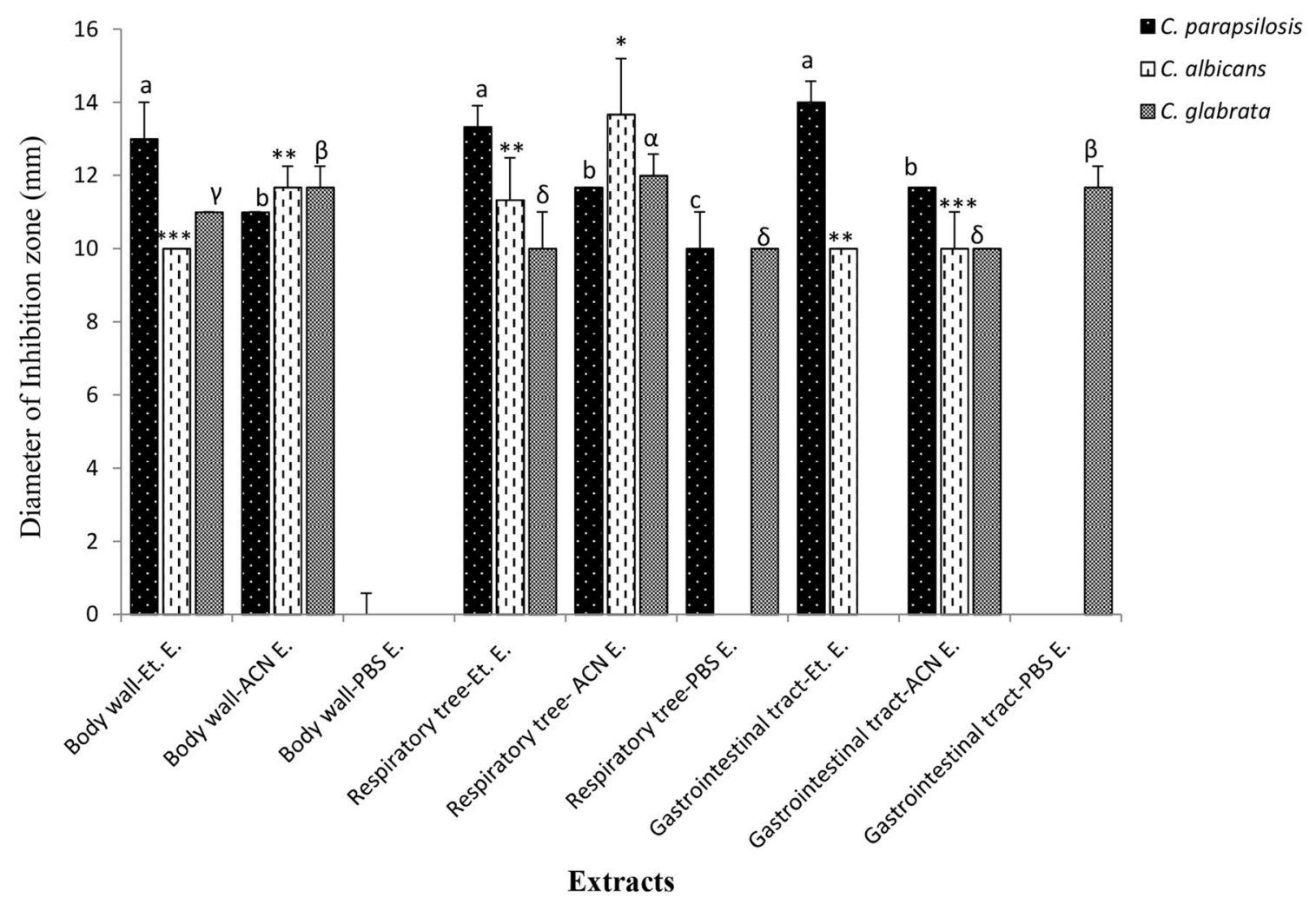

Fig. 7 The mean diameter of inhibition zone for Candida sp. under the effect of different extracts of H. leucospilota with concentrations of $1500 \mu \mathrm{g}$ well ${ }^{-1}$. Mean values bearing different superscripts are significantly different $(p<0.05)$ 
Table 1 Hemolytic activity in the sea cucumber (H. leucospilota) extracts against the red blood cells

\begin{tabular}{|c|c|c|}
\hline Tissues & Extracts & Hemolytic activity $(\%)^{\mathrm{a}}$ \\
\hline \multirow[t]{3}{*}{ Body wall } & PBS & 20 \\
\hline & $\mathrm{ACN}$ & 80 \\
\hline & Ethanol $(96 \%)$ & 60 \\
\hline \multirow[t]{3}{*}{ Respiratory tree } & PBS & 30 \\
\hline & $\mathrm{ACN}$ & 80 \\
\hline & Ethanol $(96 \%)$ & 80 \\
\hline \multirow[t]{3}{*}{ Gastrointestinal tract } & PBS & 20 \\
\hline & $\mathrm{ACN}$ & 80 \\
\hline & Ethanol $(96 \%)$ & 60 \\
\hline
\end{tabular}

${ }^{a}$ The data is presented as \% hemolysis compared to control (Triton X-100)

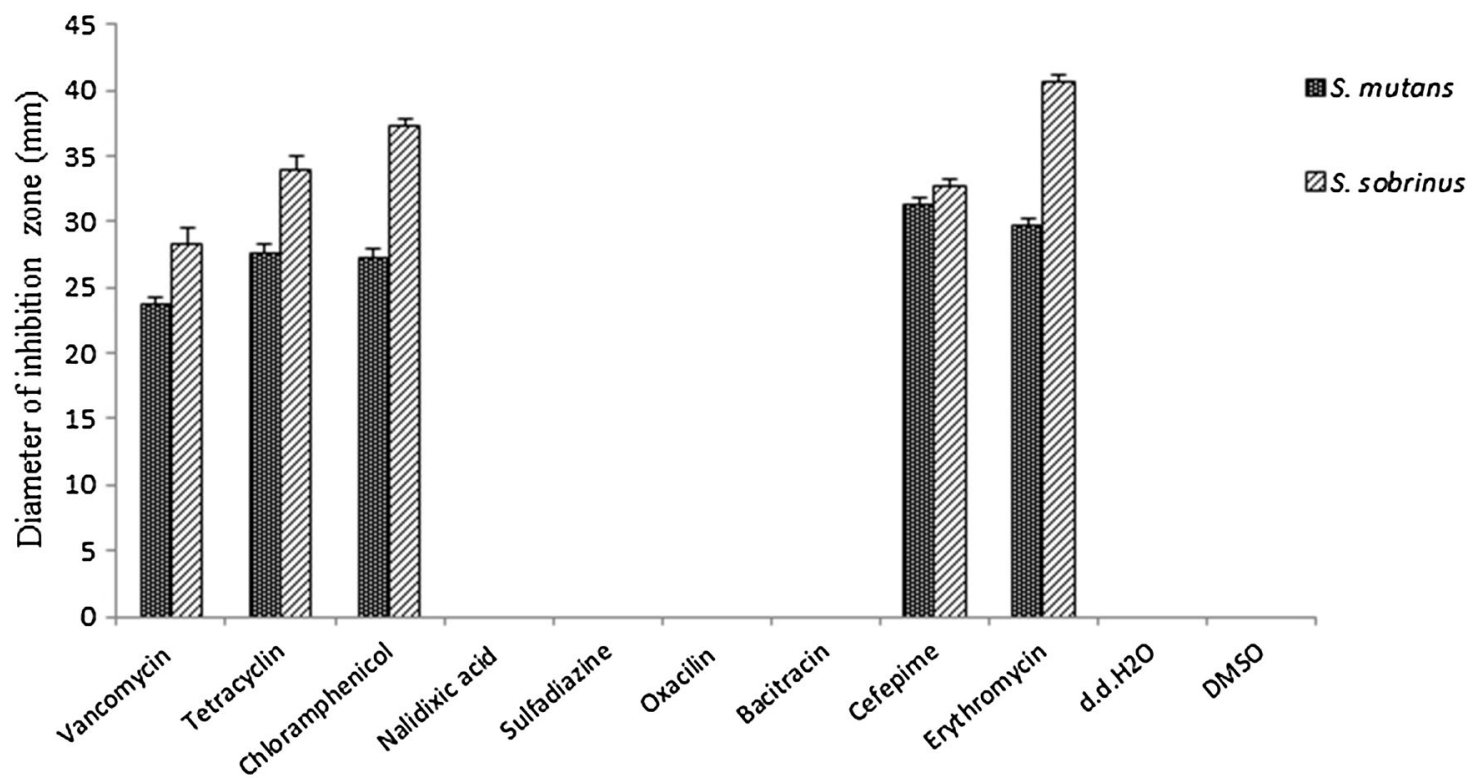

Antibiotics

Fig. 8 Antibiogram and solvents (d.d. $\left.\mathrm{H}_{2} \mathrm{O}\right)$ tests against $S$. mutans and S. sobrinus. The concentration of antibiotics and solvents was $30 \mu \mathrm{g} \mathrm{mL}^{-1}$ and $\mu \mathrm{L}$ well ${ }^{-1}$, respectively

(Gunnerus, 1767) against Gram-positive and -negative bacteria. They showed antibacterial activities in the extracts of several tissues including the body wall, coelomocyte and especially the gastrointestinal organ and the eggs from A. rubens and C. frondosa. Ridzwan et al. 1995 tested the extracts of the sea cucumbers Holothuria atra (Jaeger, 1933), H. scabra (Jaeger, 1833) and Bohadschia argus (Jaeger, 1833) against seven species of bacteria and they found that the lipid and methanol extracts had no inhibitory activities, whereas the PBS extract had severe inhibitory activity. The methanol-acetone extract of the body wall of the sea cucumber Parastichopus parvimensis (Clark, 1913) had antibacterial properties against Bacillus subtilis (Ehrenberg 1835) and Escherichia coli (Migula, 1895) (Villasin and Pomory 2000). The present study demonstrates the presence of antibacterial substances in the body wall, respiratory tree and gastrointestinal tract of the sea cucumber, H. leucospilota. As the most tropical sea cucumbers feed on live microorganisms and the organic contents found in sand or slime (Rowe 1969), there is the possibility that some pathogenic microorganisms are taken together with the food substances. Therefore, the presence of some active antibacterial substance(s) is predictable for the body defense in different parts of the sea cucumber. 


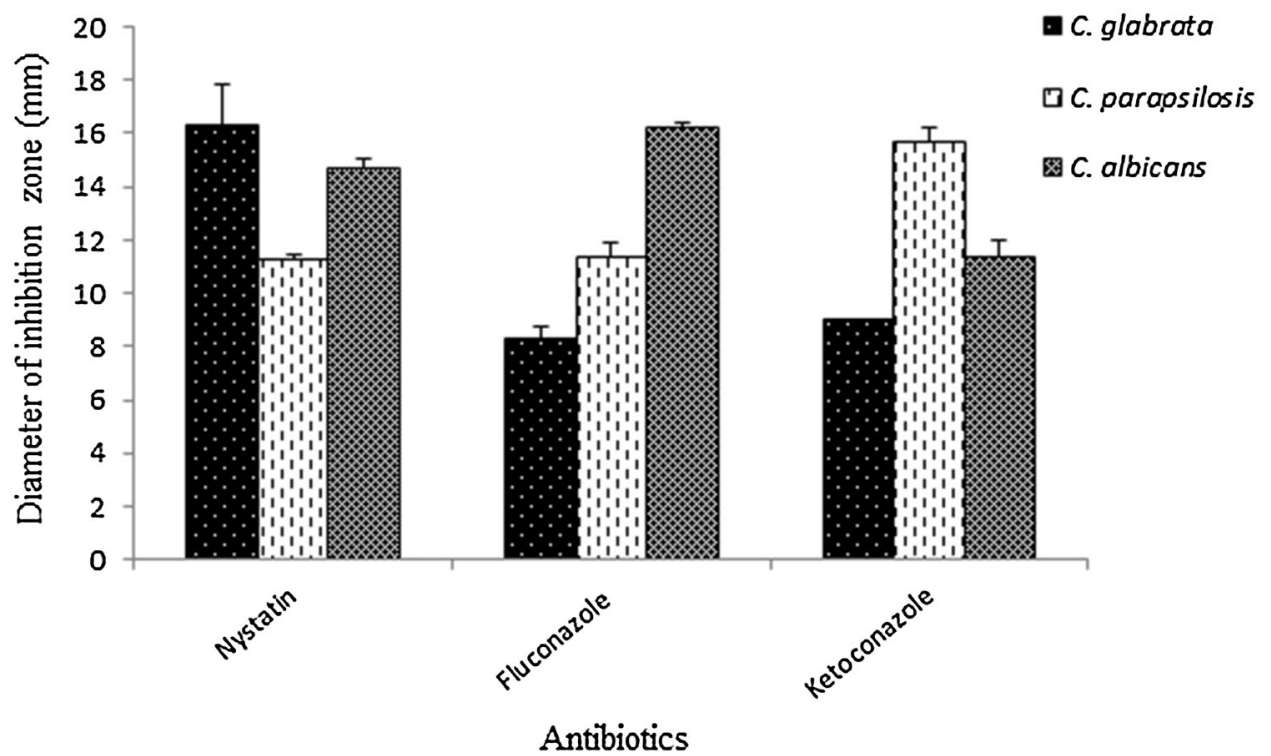

Fig. 9 Antibiogram tests against Candid strains. The concentration of antibiotics was $30 \mu \mathrm{g} \mathrm{mL}$

In the present study, among the tissues of sea cucumber, almost all extracts of the gastrointestinal tract had effect on both species of Streptococcus, whereas the effects of the extracts of body wall and respiratory tree were different. All of the extracts prepared from the body wall did not show any inhibitory effect on S. mutans, whereas its antibacterial activity against $S$. sobrinus indicated the presence of the effective active compounds in this tissue. The concentrated extracts of all tissues $\left(1500 \mu \mathrm{g}\right.$ well $\left.{ }^{-1}\right)$ had more significant inhibitory effects than other ones $\left(600 \mu \mathrm{g} \mathrm{well}{ }^{-1}\right)$. The different effects of the sea cucumber extracts can be related to the animal's habitat and its feeding on microorganisms presented in the sea bed. In addition, the antibacterial activity might be both due to the factors of the innate immune system or bacterial symbionts (Strahl et al. 2002) living on the organisms.

According to the results, as some extracts had shown antibacterial activities against these two oral streptococci, they consist of compounds which can be used for further and more in depth studies due to inhibition of oral infections caused by these bacteria.

Antifungal effects of the extracts

The antifungal activity has previously been described in some species of echinoderms (Batrakov et al. 1980; Kumar et al. 2007; Mohammadizadeh et al. 2013; Mokhlesi et al. 2011). The antifungal activity of the extracts of the respiratory tree was more than the extracts of the body wall and intestine of the sea cucumber, Holothuria scabra, against Candida albicans and Aspergillus niger (Mohammadizadeh et al. 2013). The different organs of the sea cucumber, Bohadschia marmorata, including Cuvier organ, body wall and coelomic fluid showed antifungal activities in which the Et extract of the body wall and water-alcohol extract of the Cuvier organ had the highest effects (Mokhlesi et al. 2011). In the present study, the organic extracts (ACN and $\mathrm{Et}$ ) of the different tissues of the sea cucumber, Holothuria leucospilota, had generally more antifungal effects than the PBS extracts. The observed differences between the results of this study and the other ones could be attributed to the animal habitat and the sea bed that the cucumber feed on it. In addition, the extracts of the respiratory tree had generally more antifungal activity against Candida strains which was followed by the body wall and gastrointestinal tract extracts, respectively. The antifungal activity of the respiratory tree in the sea cucumber could be referred to the defensive role of it which was demonstrated by Purcell et al. (2012). The antimicrobial activity of the body wall is evident as the first defensive line.

The studied species possesses hemolytic activity in their tissues. Several hemolytic factors had been isolated from echinoderms, including proteins (Canicatti and D'Ancona 1990), lectins (Hatakeyama et al. 1994), complement-like factors (Bertheussen 1983), and the variety of saponins (Iorizzi et al. 2001). In the 
present study, it seems that the hemolytic activities of the extracts generally are higher than their antimicrobial activities. Some extracts had highly hemolytic activity without any effects on streptococci (e.g., Et extract of respiratory tree) while some extracts showed more antibacterial activity than the hemolytic one (e.g., the PBS extract of respiratory tree). From the pharmaceutical point of view, it is a requirement that the antibacterial drugs have no side effects such as hemolytic activity (Haug et al. 2002).

\section{Conclusion}

The present study shows that the sea cucumber, Holothuria leucospilota, as an echinoderm, can be a source of antibiotics. Streptococcus sobrinus had generally been less tolerant than S. mutans against the sea cucumber extracts, therefore almost all extracts except Et extract of respiratory tree can inhibit the growth of S. sobrinus. The growth inhibition of Streptococcus sobrinus and S. mutans was generally controlled better by PBS and organic extracts, respectively. The extract of the respiratory tree had the maximum antifungal effect against Candida in comparison to the other tissues. In addition, it seemed that the sea cucumber extracts controlled the growth of Candida parapsilosis better than the other candida fungi. Finally, the extracts of the sea cucumber should be further analyzed to isolate, purify and determine the chemical structure of the antimicrobial compounds for their applications in the medicine and dentistry industries.

Open Access This article is distributed under the terms of the Creative Commons Attribution 4.0 International License (http:// creativecommons.org/licenses/by/4.0/), which permits unrestricted use, distribution, and reproduction in any medium, provided you give appropriate credit to the original author(s) and the source, provide a link to the Creative Commons license, and indicate if changes were made.

\section{References}

Aas JA, Griffen AL, Dardis SR, Lee AM, Olsen I, Dewhirst FE, Leys EJ, Paster BJ (2008) Bacteria of dental caries in primary and permanent teeth in children and young adults. J Clin Microbiol 46:1407-1417

Anaissie EJ, Ginnis M, Pfaller MA (2003) Clinical mycology, 2nd edn. Churchill Livingstone, Oxford

Anusavice K (2002) Dental caries: risk assessment and treatment solutions for an elderly population. Compend Contin Educ Dent 23:12-20

Batrakov SG, Girshovich ES, Drozhzhin NS (1980) Triterpene glycosides with Antifungal activity isolated from the sea cucumber, Cucumaria japonica. Antibiotiki 25:408-411

Becker MR, Paster BJ, Leys EJ, Moeschberger ML, Kenyon SG, Galvin JL, Boches SK, Dewhirst FE, Griffen AL (2002) Molecular analysis of bacterial species associated with childhood caries. J Clin Microbiol 40:1001-1009

Beighton D (2005) The complex oral microflora of high-risk individuals and groups and its role in the caries process. Community Dent Oral Epidemiol 33:248-255

Bertheussen K (1983) Complement-like activity in sea urchin coelomic fluid. Dev Comp Immunol 7:21-31

Bhakuni DS, Rawat DDS (2005) Bioactive marine natural products. Springer, New York

Canicatti C, D’Ancona G (1990) Biological protective substances in Marthasterias glacialis (Asteroidea) epidermal secretion. J Zool 222:445-454

Casas SM, Comesaña P, Cao A, Villalba A (2011) Comparison of antibacterial activity in the hemolymph of marine bivalves from Galicia (NW Spain). J Invertebr Pathol 106:343-345

Chhour KL, Nadkarni MA, Byun R, Martin FE, Jacques NA, Hunter N (2005) Molecular analysis of microbial diversity in advanced caries. J Clin Microbiol 43:843-849

Dabbagh AR, Sedaghat MR, Rameshi H, Kamrani E (2011) Breeding and larval rearing of the sea cucumber Holothuria leucospilota Brandt (Holothuria vegabunda Selenka) from the northern Persian Gulf, Iran. SPC Beche-De-Mer Information Bullet 31:35-38

De Melo AA, Carneiro RF, De Melo Silva W, Moura Rda M, Silva GC, De Sousa OV, Nascimento KS, Saker-Sampaio S, Nagano CS, Cavada BS, Sampaio AH (2014) HGA-2, a novel galactoside-binding lectin from the sea cucumber Holothuria grisea binds to bacterial cells. Int J Biol Macromol 64:435-442

Dewhirst FE, Chen T, Izard J, Paster BJ, Tanner ACR, Yu WH, Lakshmanan A, Wade GW (2010) The human oral microbiome. J Bacteriol 192:5002-5017

Fenical W (1996) Marine biodiversity and the medicine cabinet the status of new drugs from marine organisms. Oceanography 8:23-27

Fredalina BD, Ridzwan BH, Zainalabdin AA, Kaswandi MA, Zaiton H, Zali I, Kittakoop P, Jais AM (1999) Fatty acid composition in local sea cucumber, Stichopus chloronotus for wound healing. Gen Pharmacol 33:337-340 
Ghasempour M, Rajabnia R, Irannejad A, Hamzeh M, Ferdosi E, Bagheri M (2013) Frequency, biofilm formation and acid susceptibility of Streptococcus mutans and Streptococcus sobrinus in saliva of preschool children with different levels of caries activity. Dent Res J 10:440-445

Gowda NM, Goswami U, Islam KM (2008) T-antigen binding lectin with antibacterial activity from marine invertebrate, sea cucumber (Holothuria scabra): Possible involvement in differential recognition of bacteria. J Invertebr Pathol 99:141-145

Hatakeyama T, Kohzaki H, Nagatomo H, Yamasaki N (1994) Purification and characterization of four Ca2p-dependent lectins from the marine invertebrate, Cucumaria echinata. J Biochem 116:209-214

Haug T, Kjuu AK, Styrvold OB, Sandsdalen E, Olsen OM, Stensvag K (2002) Antibacterial activity in Strongylocentrotus droebachiensis (Echinoidea), Cucumaria frondosa (Holothuroidea), and Asterias rubens (Asteroidea). J Invertebr Pathol 1:94-102

Iorizzi M, DeMarino S, Zollo F (2001) Steroidal oligoglycosides from the asteroidea. Curr Org Chem 5:951-973

Kantarcioglu AS, Yucel A (2002) The presence of fluconazole-resistant Candida dubliniensis strain among Candida albicans isolated from immunocompromised or otherwise debilitated HIV negative Turkish patients. Revista Iberoamericana de Micología 19:44-48

Kazemi S, Heidari B, Rassa M (2016) Antibacterial and hemolytic effects of aqueous and organic extracts from different tissues of sea urchin Echinometra mathaei on pathogenic streptococci. Inter Aqua Res 8:299-308

Kiani N, Heidari B, Rassa M, Kadkhodazadeh M, Heidari B (2014) Antibacterial activity of the body wall extracts of sea cucumber (Invertebrata; Echinodermata) on infectious oral streptococci. J Basic Clin Physiol Pharmacol 25:367-373

Kumar R, Chaturvedi AK, Shukla PK, Lakshmi V (2007) Antifungal activity in triterpene glycosides from the sea cucumber Actinopyga lecanora. Bioorg Med Chem Lett 17:4387-4391

Lewbart GA (2006) Invertebrate medicine, 1st edn. Blackwell Pub, Iowa

Mohammadizadeh F, Ehsanpor M, Afkhami M, Mokhlesi A, Khazaali A, Montazeri S (2013) Evaluation of antibacterial, antifungal and cytotoxic effects of Holothuria scabra from the North Coast of the Persian Gulf. J Mycol Med 23:225-229

Mokhlesi A, Saeidnia S, Gohari AR, Shahverdi AR, Moghaddam KM, ES'haghi N (2011) Antibacterial, antifungal and cytotoxic activities of Bohadschia marmorata a sea cucumber from North coastal of Persian. Pharmacologyonline 3:1029-1038

Molero G, Diez-Orejas R, Navarro-Garcia F, Monteoliva L, Pla J, Gil C, Sánchez-Pérez M, Nombela C (1998) Candida albicans: genetics, dimorphism and pathogenicity. Int Microbiol 1:95-106

Nascimento MM, Lemos JA, Abranches J, Gonçalves RB, Burne RA (2004) Adaptive acid tolerance response of Streptococcus sobrinus. J Bacteriol 186:6383-6390

Nishikawara F, Katsumura S, Ando A, Tamaki Y, Nakamura Y, Sato K, Nomura Y, Hanada N (2006) Correlation of cariogenic bacteria and dental caries in adults. J Oral Sci 48:245-251

Okada M, Soda Y, Hayashi F, Doi T, Suzuki J, Miura K, Kozai K (2005) Longitudinal study of dental caries incidence associated with Streptococcus mutans and Streptococcus sobrinus in pre-school children. J Med Microbiol 54:661-665

Osama YA, Ridzwan BH, Muhammad T, Jamaludin MD, Masa-Aki I, Zali BI (2009) In vitro antioxidant and antiproliferative activities of three Malaysian sea cucumber species. Eur J Sci Res 37:376-387

Periyasamy N, Srinivasan M, Balakrishnan S (2012) Antimicrobial activities of the tissue extracts of Babylonia spirata Linnaeus, 1758 (Mollusca: Gastropoda) from Thanzhanguda, southeast coast of India. Asian Pac J Trop Biomed 2:36-40

Price ARG (1981) Studies on the echinoderm fauna of the western Gulf. J Nat Hist 15:1-15

Purcell SW, Samyn Y, Conand C (2012) Commercially important sea cucumbers of the world. FAO Species Catalogue for Fishery Purposes 6:1-149

Ridzwan BH, Kaswandi MA, Azman Y, Fuad M (1995) Screening for antibacterial agents in three species of sea cucumbers from coastal areas of Sabah. Gen Pharmacol 26:1539-1543

Rowe FW (1969) A review of the family Holothuriidae (Holothuroidea: Aspidochirotida). Bull Br Mus Nat Hist (Zool) 18:119-170

Sharanappa R, Vidyasagar GM (2013) Anti-Candida activity of medicinal plants. Int J Pharm Pharm Sci 5:9-16

Stepanovic S, Antic N, Dakic I, Svabicvlahovic M (2003) In vitro antimicrobial activity of propolis and synergism between propolis and antimicrobial drugs. Microbiol Res 158:353-357

Strahl E, Dobson W, Lundie JL (2002) Isolation and screening of brittlestar-associated bacteria for antibacterial activity. Curr Microbiol 44:450-459

Villasin J, Pomory CM (2000) Antibacterial activity of extracts from the body wall of Parastichopus parvimensis (Echinodermata: Holothuroidea). Fish Shellfish Immunol 10:465-467

Wang Z, Zhang H, Yuan W, Gong W, Tang H, Liu B, Li L, Yia Y, Zhanga W (2012) Antifungal nortriterpene and triterpene glycosides from the sea cucumber Apostichopus japonicus Selenka. Food Chem 132:295-300

\section{Publisher's Note}

Springer Nature remains neutral with regard to urisdictional claims in published maps and institutional affiliations. 